\title{
HÁrom TUdomÁNYÁg EGGYÉ FORMÁLÁSA, AVAGY ISMERETTERJESZTŐ KÖTET KEZDŐKNEK
}

\author{
KEREKES KRISTÓF \\ ELTE Pszichológia Doktori Iskola
}

Tracey Tokuhama-Espinosa: Mind, Brain, and Education Science: A Comprehensive Guide to the New Brain-based Teaching. New York, 2011. W.W. Norton. 438 p. ISBN: 978-0-393-70681-9

A neveléstudomány folyamatos fejlödésének egyik oka a különböző interdiszciplínák megjelenése és aktív használata a tudományos körökben. A pedagógiai pálya iránt érdeklődők egyrészt ma minden korábbinál szélesebb körü, mélyrehatóbb ismeretekkel lehetnek gazdagabbak, másrészt a képzés pszichológiai megközelítésről is szól, beleértve az agy működésének és az oktatásnak a kapcsolatát. Ezen tudományterületek alapos ismerete természetesen nem elégséges, mégis szükséges ahhoz, hogy bizonyos oktatói tevékenységeket biztonsággal alkalmazzon a pedagógus, tudósként pedig az újabb és újabb trendek, módszerek kialakítása állhat érdeklődése középpontjában.

Hasonló elvek vezérlik a Harvard Egyetemen végzett Tracey Tokuhama-Espinosát is, aki több tudományterület összeolvasztására törekszik a jobb és sikeresebb pedagógiai munka érdekében. 2011-ben megjelent könyvével (Mind, Brain and Education Science) a szükséges tanulásmechanizmusokat segítő tudományos információkat egyfajta szintézisként, holisztikus szemléletbe ágyazva ismerteti meg az olvasóval.
A könyv tekintélyes terjedelmü, szabatos, jól átgondolt, megfelelően strukturált, és első látásra - a borító és a frappáns cím alapján - átható tudományosság benyomását kelti. A bevezetőből az olvasó megismerheti a szerző lenyűgöző, szerteágazó, a könyv tartalmának megalapozottságát biztosító életútját, végigkövetheti a hosszú évek kutatásaiból és tanulmányokból álló utat a könyv megírásáig.

A szerző nem titkolt célja három tudományterület (neveléstudomány, kognitív idegtudomány és pszichológia) összeolvasztása és ezáltal egy új diszciplína megteremtése, amely a modern oktatás alapját képezheti. A három különálló terület együttes alkalmazása egy olyan egymással harmóniában álló rendszert alakít ki, amely egyrészt magában foglalja még a pszichiátriát és a neurológiát is (a pszichológia és az oktatás kapcsolatában), lehetőséget adva arra, hogy az egyetemi képzésből kikerülők könnyebben tudják értelmezni, kezelni növendékeik teljesítményét, állapotát, reakcióit, másrészt olyan összefüggésekre hívja fel a figyelmet, amellyel az olvasó már-már diagnosztikai képességre tehet szert. 
A három tudomány közvetve már a címben is megjelenik, és a könyv teljes tartalmának vázát képezi. A szerző azon igyekszik, hogy hármójuk kapcsolatait egyiket a másikkal magyarázva - részletesen bemutassa, felvetéseit pedig saját kutatási eredményeivel igazolja. Majd mindezt a tagoltságot később figyelmen kívül hagyva, egységes egészként alkalmazza különböző kérdések megválaszolására - életből hozott példákon keresztül. A módszereket elsajátító pedagógusok az új diszciplína használatával személyre szabott segítséget nyújthatnak a diákoknak, így növelve a teljesítményüket, vagyis az oktatás sikerét, egyúttal csökkentve az esetleges negatív, sértő vagy káros hatásmechanizmusokat.

Tokuhama-Espinosa - művéből tökéletesen érezhető - szándéka, hogy a pedagógusok széles körü ismeretekkel rendelkezzenek az emberi agy müködéséről, annak molekuláris és strukturális folyamatairól, valamint hogy ezeket a folyamatokat különböző kontextusban felismerjék, és szükség esetén orvosolni tudják.

A könyv nemcsak jól strukturált, illetve könnyen áttekinthetö, de kimondottan olvasmányos. A szerző maximálisan sikeresen alkalmazza az olvasási élmény megteremtéséhez szükséges közérthető, mégis tudományos szókincset, szóhasználatot és központosítást, ezáltal a mü kellően didaktikus ahhoz, hogy tankönyvként is könnyen használható legyen. A bemutatott témák kivétel nélkül figyelemfelkeltő alcímnek örvendenek, kár, hogy a szerző nem mindig bontja ki elég részletesen az említett tudományterületeket. Idegtudományi szempontokról például inkább csak általánosságban beszél, vagy éppen túl köznyelvien, annak ellenére, hogy többször is hangsúlyozza, tudományos művet adott az olvasó kezébe. Bár így nyilvánvalóan szélesebb célközönséget tud megszólítani, a címben és a bevezetésben leírt megteremtetni kívánt új diszciplína megteremtéséhez mérten, úgy érezzük, a könyv ezt a tudományágat hagyta leginkább magára.

A szerző kitér fejlődéstani kérdésekre, és ezeket egy könnyen értelmezhető, jól felépített rendszerben tálalja. Az átgondolt összefoglalás bemutatja a pedagógus számára legfontosabb alapelveket, illetve a hozzájuk kapcsolható fejlődési stádiumokat, ami a különböző korcsoporttal foglalkozó szakemberek számára mindenképpen előnyös.

$\mathrm{A} z$ útmutatóként működő fejezetek naprakészek, és gyakorlatias példákat boncolgatnak. Az olvasó valóban úgy érezheti, hogy a könyv gyakorlatorientált, és kézzel fogható, hasznos ismereteket nyújt bizonyos helyzetek, esetek megoldására. A magyarázatok és a megoldások könnyen vizualizálhatók, egyszerủ kontextusba helyezhetők, azonban hiányzik a hatásmechanizmusok részletes ismertetése: idegtudományi magyarázatokról még az azokra utaló fejezetekben sem olvashatunk, vagy legalábbis nem az elvárt mértékben. A könyv minőségét ez nagyban csorbítja, még akkor is, ha ezt a hiányt a fejezetek végén található ajánlott irodalmak jegyzéke némileg pótolja.

Írásunk elején említést tettünk arról, hogy a szerző terjedelmes müvet készített, azonban ennek funkcionalitását eddig még nem taglaltuk. A müvet olvasva többször felmerült a kérdés: „nem olvastuk ezt már korábban?” Nem véletlenül, bizonyos témakörök újra és újra előkerülnek, visszatérő motívumként szolgálnak. A történelmi kitekintések valószínúleg elhagyhatók lehetnének - már csak a rövidebb terjedelem érdekében is. A szerző mintha egy kicsit alábecsülné az olvasó kognitív képességeit. Példaként említhető a 8.1-es táblázat, amely, bár a könyv második felében található, mégis csupán olyan általánosságokat tartalmaz, mint például, 
hogy egy „jó oktató tudja, hogy az agy nem egyenlő mértékben jó mindenben".

Akik tudományos érdeklődésüket szándékoznának kielégíteni a könyvvel, inkább csak egy összefoglalót kapnak. Egy olyat azonban, amely remekül elirányít bizonyos alterületek és témák között, a fontosabb kutatók nevével és kutatási területeivel. A terjedelmes lista, amelyet az olvasó az adott fejezetekben talál, kevéssé tartalmazza az adott kutatók eredményeit, így egyben házi feladatot is biztosít az érdeklődők számára, akik a nevek mellett tartalmi tudnivalók iránt is érdeklődnek.

A szerző többször is utal arra, hogy bizonyos folyamatokat, tudományterületeket előnyös lenne ismernie a pedagógusnak. Így például a biokémiai folyamatokat a memóriaképzésnél, amelyek ismerete szükséges lehet ahhoz, hogy a pedagógus bizonyos helyzeteket megértsen és megfelelően kezeljen. Sajnos ezekről a folyamatokról sem ad a könyv megfelelő tájékoztatást.

Összességében a mű kiemelkedően széles kutatási és lexikális tudásról, ismeretanyagról ad tanúbizonyságot, kétségbevonhatatlanul mutatva a szerző érdemeit. Az olvasó szakmai előképzett- ségétől függhet, hogy a kötet kielégíti-e a tudományos érdeklődését, vagy inkább hiányérzetet kelt (ez leginkább bizonyos neurológiai és kognitív idegtudományi témákra vonatkozhat). A vázlatos és lényegi összefoglalók minden olvasó számára egyértelműsítik, hogy a szerző miket tart a legfontosabb oktatói alapelveknek, valamint egyfajta holisztikus szemléletet biztosít azoknak, akik érdeklődést mutatnak a diákokkal való nehézségek szövevényes hátterének megértése iránt. Kellő tudományos ismeretanyaggal rendelkezők számára okozhat némi hiányérzetet a témák nem megfelelő vagy nem elég alapos körüljárása, de ez szinte természetes velejárója annak, ha egy szerző nagy mennyiségü tudományos információt kíván egy müben megjeleníteni, szélesebb célközönség számára értelmezhetővé tenni. A könyvet azok számára ajánljuk, akik oktatói pályájuk során szeretnék a kapcsolódó szak- és tudományterületek összefonódási pontjait megérteni, szélesebb és komplexebb tudást kívánnak megszerezni, valamint gyakorlatorientált, valós példákon keresztül szeretnének megérteni bizonyos tudományos szempontokat.

A cikk a Creative Commons Attribution 4.0 International License (https://creativecommons.org/licenses/ by-nc/4.0/) feltételei szerint publikált Open Access közlemény, melynek szellemében a cikk bármilyen médiumban szabadon felhasználható, megosztható és újraközölhető, feltéve, hogy az eredeti szerző és a közlés helye, illetve a CC License linkje és az esetlegesen végrehajtott módosítások feltüntetésre kerülnek. 